\title{
MEASURING THE INWARD FDI POTENTIAL OF SOUTH AFRICAN REGIONS
}

\author{
W Krugell \& M Matthee, School of Economics, North-West University, Potchefstroom, South Africa
}

Purpose: The purpose of this paper is to construct an index that captures the factors expected to affect a local economy's attractiveness to foreign investors.

Problem statement: Following South Africa's reintegration into the world economy in 1994, foreign direct investment has been seen as a potential driver of growth and development. Concerns about the low investment rate in South Africa raise the possibility of augmenting domestic with foreign investment expenditure. The potential of technology spillovers and skills transfer from foreign direct investment have also been emphasised. As a result, Trade and Investment South Africa is involved in identifying, packaging and promoting investment opportunities. However, investments tend to be place-specific and this has lead to the decentralisation of foreign direct investment promotion. Currently the nine provincial development agencies are competing to attract investors and the larger local governments are also getting involved in the fray. This paper argues that some places have better potential to attract foreign investment than others. A first step to use scarce investment promotion resources more efficiently would be to measure the inward FDI potential of South African regions.

Approach: This paper uses principal components analysis to construct an index that captures the factors expected to affect a local economy's attractiveness to foreign investors. This approach draws on UNCTAD's Inward FDI Potential Index and applies it to 354 magisterial districts in South Africa for the periods 1996, 2001 and 2006. The index creates a summary measure of FDI potential.

Findings: The results show that different places present differential potential in urbanization and localization economies and market size. The high-potential locations are typically found in or around the major agglomerations, but there are a few smaller places on the periphery that offer FDI potential.

Contribution: The index should aid the location decisions of prospective investors as well as local policymakers in their efforts to promote FDI-led economic development.

Conclusion: The places with high FDI potential are not randomly scattered across South Africa, but tend to cluster together. Cities and towns can improve their attractiveness to foreign investors through the exploitation of natural resources, population growth, economic growth and strengthening links to metropolitan areas.

Key words: Foreign direct investment, investment promotion, local government, South Africa.

\section{INTRODUCTION}

Following South Africa's reintegration into the world economy in 1994, foreign direct investment (FDI) has been seen as a potential driver of growth and development. The low investment rate in South Africa requires that domestic investment be augmented with foreign investment expenditure. FDI can also provide technological spillovers and skills transfers that increase productivity and drive economic growth.

Research into the policy handles, through which FDI might be encouraged, have found that lower political risk, secure property rights, a large market, wage moderation, lower corporate tax rates and the opening up of the economy are positively related to FDI flows to South Africa (Fedderke \& Romm, 2006:24). Policymakers have also responded and Trade and Investment South Africa (TISA) is involved in identifying, packaging and promoting investment opportunities. However, investment tends to be placespecific and there has recently been a decentralisation of FDI promotion. Currently the nine provincial development agencies are competing to attract investors and the larger local governments are also getting involved. This geographical character of FDI in South Africa is yet to be examined. 
The spatial distribution of FDI depends firstly on interregional differences in factor and resource endowments. When foreign firms can choose between different regions, cities or towns, they locate in favourably endowed places. Investors also prefer to locate where other firms cluster together. Agglomeration creates a large local market and ensures diverse intermediate inputs and a thick labour market. This generates positive externalities which reduce costs and increase competitiveness.

A study of such determinants of FDI at sub-national level is unfortunately not possible in South Africa as no disaggregated FDI data are available. Data on the typical right-hand side determinants are however accessible and this paper proposes the construction of an index that captures the factors expected to affect a local economy's attractiveness to foreign investors. The approach is based on UNCTAD's Inward FDI Potential Index for countries, but it is applied to 354 magisterial districts in South Africa for the periods 1996, 2001 and 2006. The index creates a summary measure of FDI potential and hopefully will aid local policymakers to use their scarce investment promotion resources more efficiently.

The paper is structured as follows. Section 2 provides a brief overview of earlier studies of the determinants of FDI. Specific attention is given to the emerging literature that considers the determinants of FDI at regional and local levels. Section 3 explains how these determinants may also serve as measures of FDI potential and presents the construction of the FDI Potential Index. Section 4 presents the rankings of magisterial districts: the high-potential locations, the second-tier locations in the established agglomerations and the districts at the periphery that show potential to attract FDI. Section 5 focuses on the winners and losers of the liberalisation of the South African economy that has taken place over the period 1996 to 2006. Section 6 presents the implications of the research and recommendations. Section 7 concludes.

\section{LITERATURE REVIEW}

The literature on the determinants of FDI is substantial and a detailed discussion of the theories of FDI falls outside the scope of this paper. The following review is structured to first discuss the more general determinants of FDI and to focus secondly on determinants of FDI at regional and local levels.

\section{The Determinants of FDI}

Agarwal (1980:739-773) provides a classic overview of a number of hypotheses for FDI, most of which focus on the decision-making within the Multinational Enterprise (MNE). These are the Differential Rate of Return Hypothesis, the Portfolio Hypothesis, the Output and Market Size Hypothesis, The Behavioural Hypothesis, the Product Cycle Hypothesis, The Oligopolistic Reactions Hypothesis, the Internalization Hypothesis, the Liquidity Hypothesis, and the Currency Area Hypothesis. Common to many of these hypotheses is that FDI is the outcome of broad corporate strategies and investment decisions of profitmaximizing firms facing world-wide competition, where differences in cost-structures across countries lead to cross-border investment (De Mello, 1999:135).

As for the propensity of a country or region to attract FDI, Agarwal (1980:739-773) identifies political stability, incentives, and the availability of cheap labour as important determinants. The literature on the effects of FDI on the host country also emphasizes the importance of the absorptive capacity of the host country and that this affects the volume and type of FDI inflows (De Mello, 1999:135). The absorptive capacity of a country depends on a number of determinants such as institutional factors (e.g. legislation and trade regime, as well as scale factors such as the balance of payments position and size of the domestic market) and complimentary (threshold) human capital.

Given these driving forces of FDI, this paper follows Driffield (2002:556) to argue that the probability of a firm entering, or expanding into a particular location is driven by expected profits $\left(\Pi^{\mathrm{e}}\right)$. Given a lifetime of the investment of $\mathbf{N}$-periods, and the discount rate, $\mathbf{r}$, it is possible to write: 


$$
\operatorname{Pr} o b(F D I)=\phi_{1}\left[\sum_{p=0}^{N}\left(\frac{1}{1+r}\right)^{p} \prod_{t+p}^{e}\right] .
$$

In practice, this probability is unobservable. Instead, this can be re-written this as a function of placespecific characteristics (see Driffield, 2002: 556) as follows:

$$
\sum_{p=0}^{N}\left(\frac{1}{1+r}\right)^{p} \prod_{t+p}^{e}=\phi_{2}\left(X_{1 i} ; X_{2 i}\right) .
$$

Here, $X_{1 i}$ are variables that are postulated to be positively related with expected profits. From the literature the following such variables can be identified: market size, openness, infrastructure, market growth (growth in GDP per capita), sound monetary and fiscal policies, financial depth and access to natural resources.

In equation (2), the $X_{2 i}$ are variables that are negatively related with expected profits. From the literature the following can be identified: risk, high domestic investment (which is postulated to deter new entry), high industry concentration, and high scale economies (Rodrik, 1991:240). Also, high political risk and lack of good governance are often cited as having a negative impact on FDI (Jenkins \& Thomas, 2002: 44-45).

Yet, all these determinants are typically examined at an economy-wide level. To explain the location of FDI at a sub-national level one also has to look at the geographical economics literature.

\section{Geographical Economics and FDI}

In the geographical economic literature, so-called first-nature geography would be an important determinant of FDI in the form of interregional differences in factor and resource endowments. When foreign firms can choose between different regions, cities or towns, they locate in favourably endowed places.

However, there are also other forces that shape the second-nature geography of an economy and investment therein (Fujita, Krugman \& Venables, 1999:9). These are centripetal forces (e.g. market-size effects, thick labour markets and pure external economies) that pull economic activity together and are positively related to expected profits from FDI. There are also centrifugal forces (e.g. immobile factors of production, land rents and pure external diseconomies) that achieve the opposite (Fujita et al., 1999:9) and are negatively related to expected profits. The externalities related to proximity can be a significant explanation of the location of FDI at regional and local level. These externalities are broadly classified as localisation and urbanisation economies.

Localisation economies are industry-specific external economies (Brakman, Garretsen \& van Marrewijk, 2001:29-30). The industry-specialisation of a region generate external economies linked to (a) a specialised labour market and division of labour between firms and (b) the opportunity to benefit from a diversity of intermediate inputs (Boudier-Bensebaa, 2005:606-607). The Smith-Marshallian approach to the matching process on the labour market holds that the size and proximity of economic activity found in agglomerations ensure a thick labour market that allows for better matching between workers and jobs. In this approach there are two models. Helsley and Strange (1990: 208) show that a large labour market allows for a better average match between heterogeneous workers and firms' job requirements and this enhances efficiency. On the other hand, Duranton (1998:568) argues that a large labour market allows workers to become more specialized, and therefore, to be more efficient. Either way, the better matching gives rise to increasing returns in the aggregate. Chamberlinian approach to the diversity of intermediate inputs rests on the idea that a large market allows for a large number of intermediate commodities and final goods. Particularly, diversified and non-tradable inputs, such as legal and communication services, non-traded industrial inputs, maintenance and repair services and finance can enhance the productivity of 
the final sector (Fujita \& Thisse, 2002:98). The economy then displays increasing returns to scale at the level of the agglomeration.

Urbanisation economies are external economies that apply to firms across industries and capture the notion of positive spillovers for a firm as a result of total economic activity at a location (Brakman et al., 2001:29). Here the external economies are internal to the urban region and are linked to (a) better circulation of information and (b) access to infrastructure (Boudier-Bensebaa, 2005:618-619). The first is the case of knowledge sharing, learning and innovation. As industry output rises, the stock of knowledge rises and information spills over to firms. This is a positive external benefit that is not paid for, reducing cost and causing an increase in the level of output at the firm level. Thus, investing in an agglomeration raises expected profits. Glaeser, Kallal, Scheinkman and Shleifer (1992:1127-1128) distinguish between three types of these externalities: (i) Marshall-Arrow-Romer externalities that are due to knowledge sharing, learning and imitation between firms in the same industry and where local monopoly foster these spillovers; (ii) Porter externalities that are industry-specific knowledge spillovers, but where local competition fosters the spillovers; and (iii) Jacobs externalities where knowledge spillovers occur between firms of different industries and where local competition stimulates these spillovers. The second type of spillover from non-market institutions involves public goods. The supply of public goods and services provides benefits at a particular location and these benefits are often non-rivalrous and non-excludable in consumption. Non-rivalry in consumption means that each individual's or firm's consumption does not detract from any other's consumption of the good or service. Non-excludability in consumption means that it is impossible to exclude anyone from consumption - even when they are not willing to pay for the benefits. Public goods or services thus have external benefits that lower costs and enhance efficiency, giving rise to increasing returns in the aggregate. In both these cases it is important to note the importance of proximity. Proximity makes it possible to capture the spillovers of knowledge, or from infrastructure, which increase productivity and lower costs, making investments at specific locations more profitable.

In sum, the implications of geographical economics for the location of FDI are simple: FDI flows to a specific location are likely to be greater if the foreign investors are likely to benefit from (a) the economies of scale of producing for a large local market, (b) knowledge spillovers from local clusters, (c) a diversity of intermediate inputs, (d) a better matching of workers and jobs in the labour market, and (e) cost savings from the supply of infrastructure. The following section examines the results of empirical studies of the determinants of FDI.

\section{Empirics}

Empirical studies of the determinants of FDI have until recently focussed on country-level analysis in timeseries, cross-sectional and panel data designs. There is however an emerging literature that examines the determinants of FDI within countries, focussing on issues of location and agglomeration. Table 1 in the appendix provides a summary of recent research on the location of FDI. The studies show that there are a number of common factors that explain FDI at a particular location.

The size of the local market is found to be a positive determinant of FDI and is measured by GDP, GDP per capita (Belderbos \& Carree, 2002:204), Provincial GDP (Cassidy \& Andreosso-O'Callaghan, 2006:523) or Gross State Product (Bobonis \& Shatz, 2007:33). Cheng and Kwan (2000:392) used per capita income and Tuan and $\mathrm{Ng}$ (2004:684) used residents' income. Roberto (2004:10) used electrical consumption as an indicator of market size. Crozet, Mayer and Mucchielli (2004:35) calculated a market potential variable that uses the local GDP and distance-weighted GDP of neighbouring French départements.

A number of studies included local labour as a determinant of FDI. To measure the availability of labour, Boudier-Bensebaa (2005:615) and Bobonis and Shatz (2007:33) used the local unemployment rate in Hungarian regions and U.S. states respectively and found a positive relationship with FDI. Robert (2004:16), however, found that foreign investors in Italian provinces tend to avoid distressed areas with high unemployment. The relationship between the cost of labour and FDI depends on the measure used. 
Cheng and Kwan (2000:392), List (2001:967), Belderbos and Carree (2002:199), Crozet et al. (2004:41), Gao (2005:291), and Bobonis and Shatz (2007:33) all found the expected negative relationship between average wage or real wage and FDI. However, studies by Cassidy and Andreosso-O'Callaghan (2006:525) and Cheng and Stough (2006:383) controlled for labour productivity and found a positive relationship between efficiency wages and FDI in Chinese provinces. In addition, Bobonis and Shatz (2007:33) found a negative relationship between union coverage rates and FDI in U.S. states. The quality of the labour force is usually accounted for through education proxies. Cheng and Kwan (2000:396), Guimaraes, Figueiredo and Woodward (2000:127) and Gao (2005:290) found positive relationships between senior or secondary education and FDI. Deichmann, Karidis and Sayek (2003:1773) found a negative relationship between the student/teacher ratio and FDI in Turkish regions. Gao (2005:289) and Cassidy and Andreosso-O'Callaghan (2006:521) also found a positive relationship between tertiary and college education and FDI in Chinese regions.

The relationship between FDI and other factor endowments received only limited treatment in the studies under discussion. List (2001:971) found a positive link between FDI and the land area of Californian countries and Cheng and Stough (2006:380) found a negative relationship between the cost of land and FDI in Chinese provinces. Deichmann et al. (2003:1775) identified a negative link between agricultural value added in a region and FDI in Turkish regions.

The influence of first-nature geography was also captured in a number of studies. Guimaraes et al. (2000:133) found a negative link between FDI in Portuguese regions and the distance to Lisbon and Porto. Belderbos and Carree (2002:206) found that the distance from the investing country (Japan) had a negative influence on FDI in Chinese regions. Crozet et al. (2004:39) found a similar influence in the case of French regions.

Related to geography is access to infrastructure where the investment is flowing. A positive relationship was found between FDI and sea access by Belderbos and Carree (2002:207), Deichmann et al. (2003:1775-1776) as well as Cassidy and Andreosso-O'Callaghan (2006:521). Other forms of infrastructure such as high grade paved roads and inland waterways were also found to be positively related to FDI at a particular location.

A number of studies also examined the influence that policy variables have on FDI at particular locations. The best examples are in the case of the Chinese provinces: Cheng and Kwan (2000:396), Belderbos and Carree (2002:206), Gao (2005:283) and Cheng and Stough (2006:382) found positive relationships between FDI and Special Economic Zones. In other approaches, List (2001:971) found a negative relationship between county pollution regulations and FDI and Bobonis and Shatz (2007:33) found negative relationships between the corporate tax as well as unitary taxation and FDI.

Finally, almost all the studies included some measure agglomeration economies and FDI at specific locations. A range of different indicators were used. In dynamic empirical specifications previous levels of FDI were also found to be positively related to FDI flows (Cheng \& Kwan, 2000:396; Deichmann et al., 2003:1773). The presence of other foreign investors at the location or in neighbouring areas was also shown to be positively related to FDI flows (Guimaraes et al., 2000:131; Belderbos \& Carree, 2002:204208; Crozet et al., 2004:42; Roberto, 2004:21; Boudier-Bensebaa, 2005:623-624; Cheng \& Stough, 2006:379-384). Agglomeration was also measured through manufacturing density (using location quotients or employment shares) and population density. These indicators were found to be positively related to FDI at a particular location.

In sum, it can be said that the theoretical and empirical literature puts forward a range of possible determinants of FDI. Some are determinants at an economy-wide level, such as fiscal and monetary policies, financial depth and political stability. Other determinants have a place-specific character and can be examined at a sub-national level. FDI typically flows to favourably endowed places, seeking natural resources or large markets. Foreign investors prefer to locate in agglomerations to get the benefits of external economies. These include knowledge spillovers from local and other foreign firms, access to infrastructure, a diversity of intermediate inputs and a high quality labour force. These 
determinants of FDI may, however, also serve as measures of the potential of a particular locality to attract FDI. The following section sets out the construction of a FDI Potential Index.

\section{CONSTRUCTION OF THE FDI POTENTIAL INDEX}

Based on the literature presented above, it is clear that there are many determinants of FDI at a particular locality. These determinants may also be argued to serve as measures of the potential of a particular locality to attract FDI. A place or region with a large market, an educated population and proximity to agglomerations will have greater potential to attract FDI than those places that do not have these characteristics. To evaluate the FDI potential of different places objectively requires the use of a balanced set of multidimensional criteria - an FDI potential index. UNCTAD's FDI Potential Index for countries (2007) inspires the notion of a FDI potential index for sub-national places.

\section{UNCTAD's FDI Potential Index}

UNCTAD benchmarks countries' inward FDI potential and performance through the calculation of indices and ranking of countries by how they do in attracting inward direct investment. The Inward FDI Potential Index captures several factors that are expected to affect an economy's attractiveness to foreign investors:

- GDP per capita serves as an indicator of the sophistication and breadth of local demand (and of several other factors), with the expectation that higher income economies attract relatively more FDI geared to innovative and differentiated products and services.

- The rate of GDP growth over the previous 10 years is a proxy for expected economic growth.

- $\quad$ The share of exports in GDP captures openness and competitiveness.

- As an indicator of modern information and communication infrastructure, the average number of telephone lines per 1,000 inhabitants and mobile telephones per 1,000 inhabitants are used.

- Commercial energy use per capita indicates the availability of traditional infrastructure.

- The share of R\&D spending in GDP captures local technological capabilities.

- The share of tertiary students in the population indicates the availability of high-level skills.

- Country risk is measured by a composite indicator capturing some macroeconomic and other factors that affect the risk perception of investors. The variable is measured in such a way that high values indicate less risk.

- The world market share in exports of natural resources is used as a proxy for the availability of resources for extractive FDI.

- The world market share of imports of parts and components for automobiles and electronic products captures participation in the leading transnational corporation integrated production systems.

- The world market share of exports of services is used to indicate the importance of FDI in the services sector that accounts for some two thirds of world FDI.

- The share of world inward FDI stock is a broad indicator of the attractiveness and absorptive capacity for FDI, and the investment climate. 
The index is calculated as an average of the values of the 12 variables. It is normalised to yield a score between zero for the lowest scoring country and one for the highest. No weights are attached in the absence of a priori reasons to select particular weights (UNCTAD, 2007).

According to the index, South Africa is regarded as a low-potential, low performance prospect that is ranked $73^{\text {rd }}$ of 141 economies with an inward FDI potential index value of 0.182 . Table 1 shows the indicator and index values for South Africa for the period 2003-2005.

Table 1: UNCTAD FDI potential index for South Africa

\begin{tabular}{|l|r|r|}
\hline Indicator & \multicolumn{1}{|c|}{ Value } & \multicolumn{1}{|c|}{ Index value } \\
\hline Real GDP growth (\%), 1995-2005 & 3.10 & 0.480 \\
\hline GDP per capita (US\$) & 4377.00 & 0.059 \\
\hline Total exports (as \% of GDP) & 27.10 & 0.080 \\
\hline Telephone mainlines (per 1000 inhabitants) & 103.50 & 0.143 \\
\hline Mobile phones (per 1000 inhabitants) & 513.90 & 0.366 \\
\hline Energy use (per capita) & 2665.90 & 0.120 \\
\hline R\&D expenditure (\% of GDP) & 0.80 & 0.164 \\
\hline Students in tertiary education (\% of total population) & 1.53 & 0.222 \\
\hline Country risk composite rating & 72.80 & 0.597 \\
\hline Exports of natural resources (\% of world total) & 0.94 & 0.113 \\
\hline $\begin{array}{l}\text { Imports of parts/accessories of electronics or automobiles (\% } \\
\text { of world total) }\end{array}$ & 0.31 & 0.021 \\
\hline Exports of services (\% of world total) & & \\
\hline Inward FDI stock (\% of world total) & 0.44 & 0.029 \\
\hline Average FDI potential index value & 0.70 & 0.041 \\
\hline Source UNCTAD, 2007 & & 0.182 \\
\hline
\end{tabular}

Source: UNCTAD, 2007

Unfortunately it is not possible to reconstruct this index at sub-national level in South Africa due to data limitations. It is however feasible to construct a magisterial district-level index that captures some of these measures of the potential to attract FDI and to add measures of agglomeration discussed in section two. The following sub-section outlines the construction of a South African sub-national FDI potential index.

\section{The Construction of the Index}

The construction of a South African sub-national FDI potential index draws together FDI potential measures from theory, for which data are available in Global Insight's Regional Economic Explorer database. The indicators of FDI potential that are available for the construction of the index are:

- Measures of local market size: GDP per capita, an index of buying power with local income as a percentage of total income and an index of buying power with retail spending as a percentage of total retail spending,

- Measures of the agglomeration of people: total population, population density and the percentage of the population that is urbanised,

- Measures of the agglomeration of economic activity: Manufacturing employment as a percentage of total employment, the Tress index (smaller values indicate a more diversified economy) and location quotient for manufacturing ( a larger quotient reflects a comparative advantage in manufacturing),

- A measure of the openness of the local economy: Total trade as a percentage of GDP,

- A measure the cost of labour: average wage per worker in manufacturing. 
- Measures of the quality of labour: the percentage of the population with post-matric qualifications and the Human Development Index,

- Measures of local stability: the ethno-linguistic fractionalisation index (larger values indicate greater heterogeneity), the \% of people that live on less than \$2 a day, the Gini coefficient (larger values indicate greater inequality) and an overall crime index.

Magisterial districts are chosen as the spatial unit of analysis due to the availability of data over the period 1996 to 2006. Before 2000 there were 843 municipalities in South Africa, which were then reduced to 237 to constitute so-called wall-to-wall local government. This change in demarcation complicates analysis over an extended period. At the lower level of magisterial district, data are available over the whole period. Also, the magisterial districts define the location of cities and towns, whereas the municipalities are governing bodies of larger areas.

The method of constructing the index is principle component analysis. FDI potential is a latent variable that cannot be directly measured, but the analysis can identify groups of variables that measure the construct. Principle component analysis helps to screen the data, extract the factors, determine the communality and calculate the factor scores. The factor scores are then used for further analysis. The scores are aggregated to form the FDI potential index and used to identify high-potential locations. The principle component analysis is explained in detail in the following sub-section.

\section{Principle Component Analysis}

The analysis was done using SPSS 15, starting with the data for the 354 magisterial districts pooled for the periods 1996, 2001 and 2006. The first step in the analysis was to standardise the variables. Standardised z-scores were computed by the formula:

$$
z_{i k}=\frac{\left(x_{i k}-\bar{x}_{i k}\right)}{\sigma_{k}}
$$

where $x_{i k}$ is the raw value of variable $k$ for the magisterial district $i ; \bar{x}_{k}$ is the mean value of variable $k$ for all magisterial districts and $\sigma_{k}$ is the standard deviation of the variable $k$. The $z$-score of variable $k$ has a mean value of zero and a standard deviation of one.

The second step was to screen the data using a correlation matrix. The analysis requires variables that correlate fairly well, but not perfectly. When all the variables listed above were used, the correlation matrix showed high correlations between $\mathrm{HDI}$ and the percentage of people living on less that $\$ 2$ a day $(r$ $=-.887)$ and between HDI and the percentage of people with post-matric qualifications $(r=.861)$. The indices of buying power, local income as a percentage of total income and retail spending as a percentage of total retail spending, were also highly correlated $(r=.921)$. The determinant of the correlation matrix was .0000188 which is only slightly bigger than the necessary value of .00001 and this indicated a possible problem of multicollinearity. As a solution the variables HDI and local income as a percentage of total income were dropped from the analysis. Also, variables that correlate with no others should be eliminated. In this case there were insignificant correlations (one-tailed tests for $\alpha=0.05$ ) between population density and the Tress index, population density and the overall crime index and population density and the manufacturing wage per worker. Consequently, population density was also dropped from the analysis.

The third step in the analysis is to determine whether principle component analysis is appropriate. Table 2 presents the test statistics for KMO and Bartlett's test for sphericity. KMO is a measure of sampling adequacy and represents the ratio of the squared correlation between variables to the squared partial correlation between variables. The statistics range between 0 and 1 . A value close to 1 indicates that patterns of correlations are relatively compact and principle component analysis should yield distinct and reliable factors. Field (2005) indicates that values between .7 and .8 are good. Additional analysis of the 
anti-image correlation matrix shows the diagonal elements to be greater than .05 and the off-diagonal elements to be small. Thus principle component analysis is appropriate for this data.

Table 2: KMO and Bartlett's Test

\begin{tabular}{|l|l|r|}
\hline \multicolumn{2}{|l|}{$\begin{array}{l}\text { Kaiser-Meyer-Olkin Measure of Sampling } \\
\text { Adequacy. }\end{array}$} & .756 \\
\hline $\begin{array}{l}\text { Bartlett's Test of } \\
\text { Sphericity }\end{array}$ & Approx. Chi-Square & 8034.803 \\
\hline & df & 91 \\
\hline & Sig. & .000 \\
\hline
\end{tabular}

Bartlett's measure tests the null hypothesis that the original correlation matrix is an identity matrix. The test is significant, which means that the R-matrix is not an identity matrix and that there are relationships between the variables that can be included in the analysis. Again, the conclusion is that principle component analysis is appropriate.

The extraction of the factors identified three factors with eigenvalues greater than 1 . Table 3 shows the total variance explained.

Table 3: Total variance explained

\begin{tabular}{|c|c|c|c|c|c|c|c|}
\hline \multirow{2}{*}{ 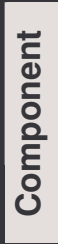 } & \multicolumn{3}{|c|}{ Initial Eigenvalues } & \multicolumn{3}{|c|}{$\begin{array}{c}\text { Extraction Sums of Squared } \\
\text { Loadings }\end{array}$} & \multirow{2}{*}{$\begin{array}{c}\text { Rotation } \\
\text { Sums of } \\
\text { Squared } \\
\text { Loadings } \\
\text { Total }\end{array}$} \\
\hline & Total & $\begin{array}{c}\% \text { of } \\
\text { Variance }\end{array}$ & $\begin{array}{c}\text { Cumulativ } \\
\text { e \% }\end{array}$ & Total & $\begin{array}{c}\% \text { of } \\
\text { Variance }\end{array}$ & $\begin{array}{c}\text { Cumulative } \\
\%\end{array}$ & \\
\hline 1 & 5.404 & 38.601 & 38.601 & 5.404 & 38.601 & 38.601 & 4.329 \\
\hline 2 & 1.799 & 12.853 & 51.453 & 1.799 & 12.853 & 51.453 & 3.166 \\
\hline 3 & 1.367 & 9.764 & 61.217 & 1.367 & 9.764 & 61.217 & 3.115 \\
\hline 4 & .980 & 7.000 & 68.217 & & & & \\
\hline 5 & .841 & 6.007 & 74.224 & & & & \\
\hline 6 & .775 & 5.538 & 79.762 & & & & \\
\hline 7 & .693 & 4.949 & 84.711 & & & & \\
\hline 8 & .571 & 4.080 & 88.791 & & & & \\
\hline 9 & .513 & 3.666 & 92.457 & & & & \\
\hline 10 & .326 & 2.330 & 94.787 & & & & \\
\hline 11 & .285 & 2.033 & 96.820 & & & & \\
\hline 12 & .188 & 1.344 & 98.164 & & & & \\
\hline 13 & .139 & .996 & 99.160 & & & & \\
\hline 14 & .118 & .840 & 100.000 & & & & \\
\hline
\end{tabular}

The eigenvalues associated with each factor represent the variance explained by that particular linear component. In this case there are three factors that explain approximately 61 per cent of the variance of the construct FDI potential. The table also shows the eigenvalues of the factors after rotation. Rotation optimizes the factor structure and it is clear that the relative importance of the three factors is equalized. Table 4 presents the communalities before and after extraction. 
Table 4: Communalities

\begin{tabular}{|l|r|r|}
\hline & \multicolumn{1}{|c|}{ Initial } & \multicolumn{1}{|c|}{ Extraction } \\
\hline Zscore: Population total & 1.000 & .720 \\
\hline Zscore: ELF & 1.000 & .413 \\
\hline Zscore: Gini coefficient & 1.000 & .488 \\
\hline Zscore: \% people on <\$2 per day & 1.000 & .756 \\
\hline Zscore: Post-matric qualification \% of pop & 1.000 & .733 \\
\hline Zscore: Urbanisation \% & 1.000 & .680 \\
\hline Zscore: Manufac employ \% of total & 1.000 & .750 \\
\hline Zscore: Index of buying power retail \% of & 1.000 & .764 \\
total & & .656 \\
\hline Zscore: GDP per capita & 1.000 & .460 \\
\hline Zscore: Tress index & 1.000 & .832 \\
\hline Zscore: Location quotient of manufacturing & 1.000 & .260 \\
\hline Zscore: Trade \% of GDP & 1.000 & .708 \\
\hline Zscore: Overall crime index & 1.000 & .350 \\
\hline Zscore: Manufac wage per worker & 1.000 & \\
\hline
\end{tabular}

The communalities reflect the common variance. Put in a different way, the communalities represent the amount of variance in each variable that can be explained by the three factors that have been retained. That is, 72 per cent of the variance associated with population is shared variance.

In this analysis, the factor extraction was done with orthogonal as well as oblique rotation. The component matrix before rotation and the results of the orthogonal rotation are not reported here. The oblique rotation allows for the factors to be related and provided the best results. Then the factor matrix is split into pattern and structure matrices which are shown in tables 5 and 6 below.

\section{Table 5: Pattern matrix}

\begin{tabular}{|c|c|c|c|}
\hline & \multicolumn{3}{|c|}{ Component } \\
\hline & 1 & 2 & 3 \\
\hline Zscore: Overall crime index & .877 & & \\
\hline Zscore: Urbanisation \% & .806 & & \\
\hline Zscore: \% people on $<\$ 2$ per day & -.774 & & \\
\hline Zscore: Post-matric qualification $\%$ of pop & .694 & & \\
\hline Zscore: GDP per capita & .577 & .485 & \\
\hline Zscore: ELF & .565 & & \\
\hline Zscore: Population total & & .835 & \\
\hline $\begin{array}{l}\text { Zscore: Index of buying power retail \% of } \\
\text { total }\end{array}$ & & .806 & \\
\hline Zscore: Gini coefficient & & -.488 & \\
\hline Zscore: Trade \% of GDP & & & \\
\hline Zscore: Location quotient of manufacturing & & & -.908 \\
\hline Zscore: Manufac employ \% of total & & & -.749 \\
\hline Zscore: Manufac wage per worker & & & -.582 \\
\hline Zscore: Tress index & & & .521 \\
\hline
\end{tabular}

Extraction Method: Principal Component Analysis.

Rotation Method: Oblimin with Kaiser Normalization.

a Rotation converged in 14 iterations.

The pattern matrix shows the factor loadings for the three factors identified above. Factor 1 seems to present urbanisation economies with measures for GDP, education, urbanisation, poverty, crime and 
ethno-linguistic fractionalisation. Poverty as measured by the percentage of people living on less than $\$ 2$ per day shows a negative relationship with urbanisation economies. Factor 2 seems to consist of the market size variables where the population, GDP, index of buying power and inequality are included. Here, inequality, as measured by the Gini coefficient, shows a negative relationship with the size of the market that would show potential to attract FDI. Factor 3 then makes up the measures of localisation economies in the forms of the location quotient, manufacturing employment, wage per worker and Tress index. It seems that less diversified economies offer localisation economies and a concentration of manufacturing output and employment, as well as higher wages, are negatively related to localisation economies.

Squaring the factor loadings gives an estimate of the amount of variance in a factor accounted for by a variable. For example, GDP per capita accounts for 33 per cent of the variance in factor 1 and population accounts for 69 per cent of variance in factor 2 .

The pattern matrix contains information about the unique contribution of a variable to a factor, but ignores that shared variance. The shared variance is shown by the structure matrix.

Table 5: Structure matrix

\begin{tabular}{|l|r|r|r|}
\hline & \multicolumn{3}{|c|}{ Component } \\
\hline & $\mathbf{1}$ & $\mathbf{2}$ & $\mathbf{3}$ \\
\hline Zscore: \% people on <\$2 per day & -.847 & & .405 \\
\hline Zscore: Urbanisation \% & .819 & & \\
\hline Zscore: Overall crime index & .815 & & \\
\hline Zscore: Post-matric qualification \% of pop & .773 & .540 & \\
\hline Zscore: GDP per capita & .666 & .601 & \\
\hline Zscore: ELF & .624 & & \\
\hline $\begin{array}{l}\text { Zscore: Index of buying power retail \% of } \\
\text { total }\end{array}$ & .418 & .840 & \\
\hline Zscore: Population total & & .814 & \\
\hline Zscore: Gini coefficient & -.473 & -.599 & \\
\hline Zscore: Trade \% of GDP & & .457 & \\
\hline Zscore: Location quotient of & & & -.909 \\
manufacturing & & & -.810 \\
\hline Zscore: Manufac employ \% of total & & & -.589 \\
\hline Zscore: Manufac wage per worker & & & .579 \\
\hline Zscore: Tress index & -.470 & & \\
\hline
\end{tabular}

Extraction Method: Principal Component Analysis.

Rotation Method: Oblimin with Kaiser Normalization.

From the structure matrix it is clear that several variables load highly onto more than one factor. Note that the openness of the economy variable now has a factor loading in the market size factor 2 .

In sum, the component correlation matrix showed that all the factors are interrelated to some degree. This means that the obliquely rotated solution is meaningful.

Based on the analysis above the final step was to calculate factor scores for each of the magisterial districts. The analysis was repeated for 1996, 2001 and 2006. The factor scores represent indicators of the market size, localisation and urbanisation economies at each location and were summed to form a composite indicator of FDI potential. The following section presents the rankings of magisterial districts: the high-potential locations, the second-tier locations in the established agglomerations and the districts at the periphery that show potential to attract FDI. 


\section{RESULTS AND RANKINGS}

A box plot is a convenient way to assess the distribution of FDI potential across South Africa's magisterial districts. Figure 1 shows a skewed distribution of FDI potential where most places have little potential and there are a few high-potential outliers.

These outliers are the "usual suspects" of well-performing magisterial districts in South Africa. These places include four major metropolitan areas: Johannesburg, Pretoria, Cape Town and Durban. Others are close to these agglomerations, for example, Randburg is adjacent to Johannesburg in the west. Germiston and Kempton Park lie to the east and are part of the Ekurhuleni metropolitan area. Vanderbijlpark is also part of the greater Witwatersrand area and lies to the south of Johannesburg. Similarly, Goodwood and Wynberg are close to the Cape. Port Elizabeth is a major port city on the south coast.

Figure 1: Box plots of the FDI potential index

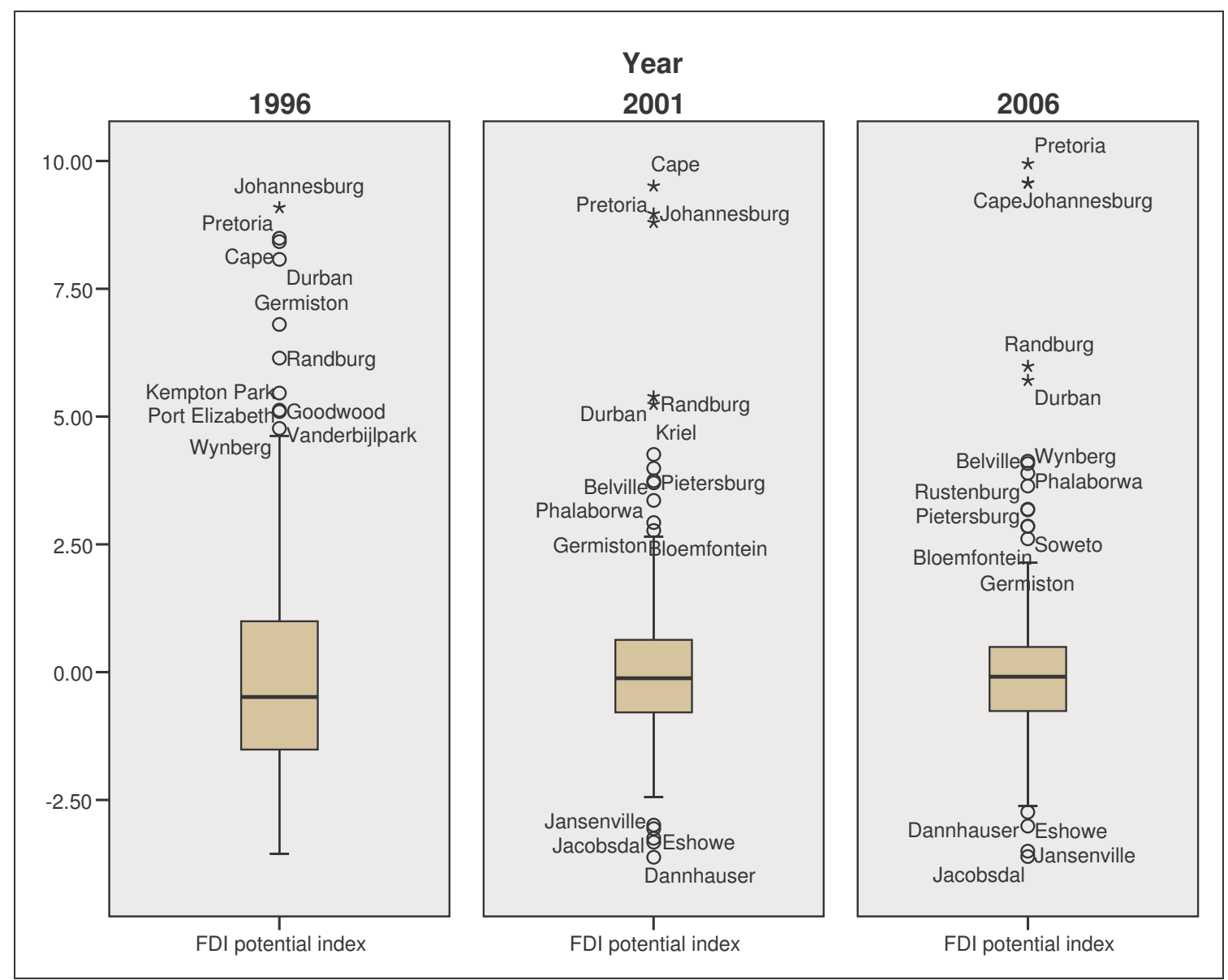

Figure 1 also shows a number of changes through 2001 and 2006. The distribution becomes more leptokutic with more places clustered around the mean. Pretoria, the Cape and Johannesburg consolidated their positions as the high-potential locations for FDI, but regional centres like Pietersburg, Phalaborwa and Bloemfontein emerged as contenders in 2001. In 2006, Rustenburg and Soweto also joined their ranks as high potential locations for FDI. For a more detailed discussion of the rankings table 6 presents the top 30 magisterial districts by FDI potential index in 1996.

For a more detailed discussion of the rankings, it is useful to consider the geography of the magisterial districts. The places with high FDI potential are not randomly scattered across South Africa, but tend to 
cluster together around the main port cities as well as in the economic agglomeration of the Gauteng province. In the discussion that follows the above magisterial districts are grouped as high-potential locations, the close neighbours in the established agglomerations, and the potential at the periphery.

Table 6: FDI potential index ranking in 1996

\begin{tabular}{|l|r|r|r|r|}
\hline $\begin{array}{c}\text { Magisterial } \\
\text { district }\end{array}$ & $\begin{array}{c}\text { Urbanisation } \\
\text { economies }\end{array}$ & $\begin{array}{c}\text { Market } \\
\text { size }\end{array}$ & $\begin{array}{c}\text { Localisation } \\
\text { economies }\end{array}$ & $\begin{array}{c}\text { FDI } \\
\text { potential } \\
\text { index }\end{array}$ \\
\hline Johannesburg & 3.19 & 4.96 & 0.94 & 9.09 \\
\hline Cape & 4.28 & 2.78 & 1.43 & 8.49 \\
\hline Pretoria & 2.88 & 4.53 & 1.01 & 8.42 \\
\hline Durban & 2.38 & 4.03 & 1.66 & 8.08 \\
\hline Germiston & 2.50 & 2.04 & 2.26 & 6.80 \\
\hline Randburg & 2.63 & 1.94 & 1.58 & 6.15 \\
\hline Port Elizabeth & 0.95 & 2.80 & 1.71 & 5.46 \\
\hline Kempton Park & 1.12 & 2.20 & 1.81 & 5.13 \\
\hline Goodwood & 1.06 & 3.04 & 1.00 & 5.10 \\
\hline Vanderbijlpark & 0.28 & 1.69 & 3.14 & 5.10 \\
\hline Wynberg & 1.49 & 2.90 & 0.39 & 4.77 \\
\hline Alberton & 0.89 & 2.35 & 1.38 & 4.62 \\
\hline Sasolburg & 1.01 & 0.34 & 3.24 & 4.59 \\
\hline Pinetown & 0.97 & 1.94 & 1.68 & 4.58 \\
\hline Boksburg & 1.36 & 1.63 & 1.58 & 4.57 \\
\hline Uitenhage & 0.50 & 0.90 & 2.88 & 4.28 \\
\hline Springs & 1.16 & 0.88 & 2.04 & 4.07 \\
\hline Soweto & 0.40 & 5.67 & -2.07 & 4.00 \\
\hline Belville & 0.92 & 1.89 & 1.16 & 3.97 \\
\hline Wonderboom & 1.11 & 1.15 & 1.65 & 3.91 \\
\hline Kuilsrivier & 1.10 & 1.72 & 1.02 & 3.84 \\
\hline Roodepoort & 1.52 & 1.50 & 0.81 & 3.84 \\
\hline Inanda & 0.09 & 2.87 & 0.81 & 3.77 \\
\hline Lower & -0.42 & 0.85 & 3.18 & 3.62 \\
\hline Umfolozi & 1.01 & 0.93 & 1.67 & 3.61 \\
\hline Vereeniging & 1.07 & 1.44 & 1.02 & 3.53 \\
\hline Benoni & 0.98 & 0.37 & 2.18 & 3.52 \\
\hline Highveld Ridge & 1.32 & 0.12 & 2.06 & 3.50 \\
\hline Middelburg & 0.27 & 4.50 & -1.30 & 3.48 \\
\hline Mitchellsplain & 0.86 & 1.01 & 1.47 & 3.35 \\
\hline East London & & & & \\
\hline & & & & \\
\hline
\end{tabular}

Table 6 shows that Johannesburg had the greatest FDI potential in the 1996 index ranking. However, Johannesburg is not a isolated magisterial district but the centre of South Africa's main economic agglomeration. Along with Johannesburg, one should also consider the FDI potential of a number of other magisterial districts. To the east of Johannesburg lie Germiston, Kempton Park, Boksburg, Springs and Benoni. To the west are Randburg and Roodepoort. To the south lie Alberton, Soweto, Vereniging and Vanderbijl. From the breakdown of the index it is clear that the different place do presented differences in FDI potential in 1996. Johannesburg offered urbanisation economies and market size. The East Rand locations offered a combination of urbanisation and localisation economies and market size. Their historical industrial base clearly showed in the importance of the localisation economies. Randburg 
and Roodepoort showed stronger urbanisation economies and Soweto presented market size. Alberton and Vereniging offered market size and localisation economies and in the case of Vanderbijl localisation economies dominated.

Ranked second by FDI potential index in table 6 was Cape Town. Much like the case of Johannesburg, it is limiting to consider only the Cape magisterial district. The greater metropolitan area also includes Wynberg and Goodwood that offered market size and urbanisation economies and Belville that showed market size and urbanisation economies in 1996. Within close proximity there is also Mitchellsplain and Kuilsrivier. Kuilsrivier offered a combination of urbanisation and localisation economies and market size where Mitchellsplain, like Soweto, presented market size.

The third of the high performers was Pretoria. Whether Pretoria is in fact a separate cluster may be point of contention. One may argue that it forms the northern part of the greater Gauteng cluster around Johannesburg. In fact, the Pretoria magisterial district is only 50 kilometers apart, separated by the Randburg magisterial district. Approximately 35 kilometres north of Pretoria, the neighbouring Wonderboom magisterial district also showed high FDI potential.

The last of the high performers was Durban that was ranked fourth highest by FDI potential in 1996. Durban is South Africa's busiest port, but unlike Johannesburg or Cape Town, Durban has fewer neighbouring magisterial districts that also showed significant FDI potential. Pinetown and Inanda are found in the rankings and showed market size and urbanisation economies.

Aside from the high potential locations and their established agglomerations, table 6 also shows a number of magisterial districts at the periphery that also show FDI potential far above the national average. These magisterial districts include the Eastern Cape port cities of Port Elizabeth and East London. Port Elizabeth is ranked $7^{\text {th }}$ in the index and showed market size and localisation economies, which is different to the other major cities. The industrial centre of Uitenhage is close by and presented significant localisation economies. In KwaZulu-Natal one finds a single outlier at the periphery in the form of the Lower Umfolozi magisterial district. It is approximately 200 kilometres to the north of Durban and the location of heavy industry and the Richardsbay harbour. It presented the second highest localisation economies value in the index. In the Free State province, only the magisterial district of Sasolburg showed exceptional FDI performance in 1996. It is the home of South Africa's petrochemicals industry which can clearly be seen from the localisation economies it presented in 1996. It may however be argued that Sasolburg should be included in the Johannesburg agglomeration, as it lies just south of Vanderbijl and is approximately 67 kilometers from Johannesburg. In Mpumalanga province there are two magisterial districts, Middelburg and Highveld Ridge, that showed significant FDI potential in 1996. These places are located along the so-called Mpumalanga development corridor that links the agglomerations of Johannesburg and Pretoria with Maputu in neighbouring Mozambique. Both these locations offered more localisation economies in 1996.

In sum, this section has shown that the FDI potential index provides a reasonable description of the geographical clustering of investment potential in South Africa. The greatest potential lies in Gauteng, Durban and Cape Town and the close neighbours in the established agglomerations make an important contribution. Though, the focus should not be limited to the agglomerations - a number of magisterial districts with high FDI potential have been identified on the periphery. Such places present opportunities for prospective investors and local policymakers.

Along with the identification of FDI potential, a comparison of indices over the period 1996 to 2006 may also be a useful indicator of the places that have benefited from recent liberalisation. The following section presents the index rankings of FDI potential over the periods 1996, 2001 and 2006.

\section{WHO BENEFITED FROM DEMOCRACY AND LIBERALISATION?}


Since 1994 South Africa has liberalized its trade and investment environment and phased down tariff barriers and exchange control. The reintegration into the world economy has lead to numerous structural changes in the South African economy. One would expect that it also influenced the FDI potential of South Africa's magisterial districts. The FDI potential index provides a way to assess this impact of liberalization. Table 7 shows the FDI potential index rankings of the top 30 magisterial districts in 1996, 2001 and 2006. The choice of periods is guided by data considerations - 1996 and 2001 were census years, which aids the robustness of sub-national data and 2006 is the latest year available in the Regional Explorer database.

Table 7 shows that Pretoria, Johannesburg, the Cape and Durban still dominated the FDI potential index in 2006. Other high-potential locations that held on to their places in the top 30 include Germiston, Randburg, Soweto, Bellville, Wynberg, Mitchellsplain and Port Elizabeth.

Table 7: FDI potential rankings in 1996, 2001 and 2006

\begin{tabular}{|l|r|r|r|r|r|r|r|}
\hline Magisterial district & $\begin{array}{r}1996 \\
\text { rank }\end{array}$ & $\begin{array}{r}2001 \\
\text { rank }\end{array}$ & $\begin{array}{c}2006 \\
\text { rank }\end{array}$ & $\begin{array}{c}\text { Urbanisation } \\
\text { economies }\end{array}$ & $\begin{array}{c}\text { Market } \\
\text { size }\end{array}$ & $\begin{array}{c}\text { Localisation } \\
\text { economies }\end{array}$ & $\begin{array}{c}\text { FDI } \\
\text { potential } \\
\text { index } \\
2006\end{array}$ \\
\hline Pretoria & 3 & 3 & 1 & 3.44 & 6.51 & -0.01 & 9.95 \\
\hline Johannesburg & 1 & 2 & 2 & 3.22 & 6.51 & -0.16 & 9.57 \\
\hline Cape & 2 & 1 & 3 & 4.45 & 5 & 0.12 & 9.56 \\
\hline Randburg & 6 & 5 & 4 & 3.00 & 3.66 & -0.68 & 5.98 \\
\hline Durban & 4 & 4 & 5 & 2.5 & 4.53 & -1.32 & 5.71 \\
\hline Bellville & 19 & 7 & 6 & 2.18 & 2.52 & -0.58 & 4.13 \\
\hline Phalaborwa & 71 & 10 & 7 & 1.52 & 1.34 & 1.22 & 4.08 \\
\hline Wynberg & 11 & 8 & 8 & 1.42 & 2.86 & -0.39 & 3.89 \\
\hline Kriel & 84 & 6 & 9 & 1.36 & 0.98 & 1.31 & 3.64 \\
\hline Pietersburg & 47 & 9 & 10 & 2.57 & 0.46 & 0.15 & 3.19 \\
\hline Rustenburg & 63 & 14 & 11 & 0.55 & 2.01 & 0.61 & 3.17 \\
\hline Germiston & 5 & 11 & 12 & 2.71 & 1.89 & -1.74 & 2.86 \\
\hline Soweto & 18 & 13 & 13 & 0.20 & 2.59 & 0.06 & 2.85 \\
\hline Bloemfontein & 54 & 12 & 14 & 1.54 & 0.95 & 0.12 & 2.61 \\
\hline Thabazimbi & 115 & 16 & 15 & 0.74 & 0.63 & 0.78 & 2.14 \\
\hline Roodepoort & 22 & 18 & 16 & 1.66 & 1.28 & -0.81 & 2.12 \\
\hline Port Elizabeth & 7 & 20 & 17 & 0.68 & 3.27 & -1.91 & 2.04 \\
\hline Ellisras & 111 & 15 & 18 & 1.03 & 0.18 & 0.76 & 1.98 \\
\hline Somersetwest & 39 & 17 & 19 & 1.89 & 0.41 & -0.44 & 1.86 \\
\hline Simonstown & 40 & 19 & 20 & 1.81 & 0.38 & -0.35 & 1.84 \\
\hline Mitchellsplain & 29 & 22 & 21 & 0.26 & 1.63 & -0.08 & 1.81 \\
\hline Kuruman & 147 & 37 & 22 & 0.84 & 0.10 & 0.83 & 1.77 \\
\hline Postmasburg & 102 & 31 & 23 & 0.88 & 0.19 & 0.69 & 1.76 \\
\hline Nelspruit & 35 & 24 & 24 & 1.88 & 0.64 & -0.89 & 1.64 \\
\hline Umlazi & 53 & 38 & 25 & 0.10 & 1.14 & 0.22 & 1.47 \\
\hline Soshanguve & 70 & 21 & 26 & 0.60 & 0.30 & 0.52 & 1.43 \\
\hline Oberholzer & 129 & 23 & 27 & 0.19 & 0.46 & 0.75 & 1.4 \\
\hline Hopefield & 131 & 26 & 28 & 1.01 & -0.28 & 0.66 & 1.39 \\
\hline Strand & 52 & 28 & 29 & 1.84 & -0.22 & -0.26 & 1.35 \\
\hline Bedford & & 47 & 30 & -0.1 & -0.33 & 1.71 & 1.28 \\
\hline
\end{tabular}


In 2006 there were a number of new entries to the top 30. It is important to note the reduced variance of the distribution. Between 1996 and 2006 the standard deviation of FDI potential index values from the mean declined from 2.1 to 1.5. This means that magisterial districts with much lower index values entered the top 30 in 2006, than were the case in 1996. Few of these new entrants present significant FDI potential. The notable cases include Phalaborwa, Rustenburg, Pietersburg and Bloemfontein. Pieterburg/Polokwane and Bloemfontein are provincial capitals and saw significant population growth and economic growth over the period. The breakdown of the index shows that they offered urbanisation economies in 2006. Rustenburg is in the North West Province and have recently benefited significantly from the boom in the platinum mining industry. It was one of the fastest growing magisterial districts in the country between 1996 and 2006 and the index shows that it offered mainly market size potential to attract FDI. Similarly, Phalaborwa's success is owed to natural resources, particularly the mining of phosphates and copper. The breakdown of the index showed that in 2006 Phalaborwa provided a balance of urbanisation and localisation economies, as well as market size.

Many of the smaller new entrants into the top 30 presented specific draws for potential foreign investors. For example, Simonstown, Somersetwest and Strand are close to Cape Town and offer urbanisation economies. In similar fashion Soshanguve is part of the Pretoria agglomeration and Oberholzer is close to Johannesburg. Umlazi is close to the greater Durban metropolitan area and presented market size potential. Like Pietersburg/Polokwane and Bloemfontein, Nelspruit is a provincial capital and offered urbanisation economies. What these findings imply for policymakers are discussed in the following section.

\section{IMPLICATIONS AND RECOMMENDATIONS}

This paper investigated the geographical character of FDI in South Africa. FDI is regarded as a potential driver of growth and development for South Africa. However, investment promotion resources are scarce and have to be effectively allocated to those places that have the potential to attract inward FDI. The aim of this paper is to provide an index that captures the factors expected to affect a local economy's attractiveness to foreign investors. This will ultimately aid policymakers in their allocation of investment promotion resources.

FDI typically flows to favourably endowed places, seeking natural resources or large markets. Foreign investors prefer to locate in agglomerations to receive the benefits of external economies (e.g. knowledge spillovers from local and other foreign firms, access to infrastructure, a diversity of intermediate inputs and a high quality labour force). The key findings from the FDI potential index is that high FDI potential is not randomly scattered across South Africa, but tends to cluster together around the main port cities as well as in the economic agglomeration of the Gauteng province. Magisterial districts in and around the large agglomerations (metropolitan areas) came out at the top in 1996, 2001 and 2006. They are Gauteng, Durban and Cape Town. Several regional centres joined the top ranking districts in 2001 (e.g. Pietersburg, Phalaborwa and Bloemfontein) and 2006 (e.g. Rustenburg and Soweto).

The aim of this article has not been to identify policy levers, but to identify the places where policies are more likely to bear fruit. Currently, the national industrial policy framework states that work is underway to identify specific areas and corridors in which high economic need coincides with good economic potential (DTI, 2007:49). The implication of this research is that great care should be taken when government tries to pick winners and the location of investment and development initiatives should be scrutinised by researchers and policymakers alike. This article has aimed to make an input to such a process.

\section{CONCLUSIONS}

In conclusion, the article shows that different places present differential potential in urbanization and localization economies and market size. The high-potential locations are typically found in or around the major agglomerations, but there are a few smaller places on the periphery that offer FDI potential.

Their ranking can be attributed to the exploitation of natural resources, population growth, economic growth and their proximity to metropolitan areas (i.e. their market-size potential). It is in these magisterial 
districts, located on the periphery, that opportunities for prospective investors and local policymakers are presented.

\section{LIST OF REFERENCES}

Agarwal JP. 1980. Determinants of foreign direct investment: A survey, Weltwirtschaftliches Archiv, 116(4):739-773.

Belderbos R \& Carree M. 2002. The location of Japanese investments in China: Agglomeration effects, Keiretsu and firm heterogeneity. Journal of Japanese and International Economics, 16:195-211.

Bobonis GJ \& Shatz HJ. 2007. Agglomeration, adjustment and state policies in the location of foreign direct investment in the United States. The Review of Economics and Statistics, 89:30-43.

Boudier-Bensebaa F. 2005. Agglomeration economies and location choice: Foreign direct investment in Hungary. Economics of Transition, 13:205-628.

Brakman S, Garretsen H \& Van Marrewijk C. 2001. An introduction to geographical economics: Trade, location and growth. Cambridge: Cambridge University Press.

Cassidy JF \& Andreosso-O’Callaghan B. 2006. Spatial determinants of Japanese FDI in China. Japan and the world economy, 18:512-527.

Cheng LK \& Kwan YK. 2000. What are the determinants of the location of foreign direct investment? The Chinese experience. Journal of International Economics, 51:379-400.

Cheng S \& Stough RR. 2006. Location decisions of Japanese new manufacturing plants in China: A discrete choice analysis. Annals of Regional Science, 40:369-387.

Crozet M, Mayer T \& Mucchielli JL. 2004. How do firms agglomerate? A study of FDI in France. Regional Science and Urban Economics, 34:27-54.

Deichmann Y, Karidis S \& Sayek S. 2003. Foreign direct investment in Turkey: Regional determinants. Applied Economics, 35:1767-1778.

De Mello LR. 1999. Foreign direct investment-led growth: Evidence from time series and panel data. Oxford Economic Papers, 51(1):133-151.

Department of Trade and Industry. 2007. A new industrial policy framework [Online] Available from: http://www.dti.gov.za/ [Accessed: 03/06/2008].

Driffield N. 2002. Determinants of inward investment in the UK, A panel analysis. Applied Economics, 34(5): 555-560.

Duranton G. 1998. Labour specialisation, transport costs and city size. Journal of Regional Science, 38(4):533-573.

Fedderke JW \& Romm AT. 2004. Growth impact and determinants of foreign direct investment in South Africa, 1956-2003. ERSA Working paper no. 12.

Field A. 2005. Discovering statistics using SPSS. London: Sage.

Fujita M, Krugman PR \& Venables AJ. 1999. The Spatial Economy. Cambridge Mass. MIT Press. Fujita M \& Thisse JF. 2002. Economics of agglomeration. Cambridge: Cambridge University Press. 
Gao T. 2005. Labour quality and the location of foreign direct investment: Evidence from China. China Economic Review, 16:274-292.

Gleaser E, Kallal H, Scheinkman J \& Shleifer A. 1992. Growth in cities. Journal of Political Economy, 100(6):1126-1152, December.

Guimaraes P, Figueiredo O \& Woodward D. 2000. Agglomeration and the location of foreign direct investment in Portugal. Journal of Urban Economics, 47:115-135.

Helsley RW \& Strange WC. 1990. Matching and agglomeration economies in a system of cities. Regional Science and Urban Economics, 20(2):189-212, September.

Jenkins C \& Thomas L. 2002. Foreign direct investment in Southern Africa: Determinants, characteristics and implications for economic growth and poverty alleviation. Mimeo: CSAE/Oxford and CREFSA, London School of Economics.

List JA. 2001. U.S. county-level determinants of inbound FDI: Evidence from a two-step modified count data model. International Journal of Industrial Organisation, 19:953-973.

Roberto B. 2004. Acquisition versus greenfield investment: The location of foreign manufacturers in Italy. Regional Science and Urban Economics, 34:3-25.

Rodrik D. 1991. Policy uncertainty and private investment in developing countries. Journal of Development Economics, 36(2): 229-242.

Tuan C \& Ng LFY. 2004. Manufacturing agglomeration as incentives to Asian FDI in China after WTO. Journal of Asian Economies, 15:673-693.

UNCTAD, 2007. FDI potential and performance indices [Online] Available from: http://www.unctad.org/Templates/Page.asp?intltemID=2468\&lang=1

Zietsman HL, Ferreira SLA \& Van Der Merwe IJ. 2006. Measuring the growth capability of towns in the Western Cape, South Africa. Development Southern Africa, 23(5). 


\section{APPENDIX}

Table A: Summary of recent research

\begin{tabular}{|c|c|c|c|}
\hline Author(s) & Location & Data and method & Determinants \\
\hline $\begin{array}{l}\text { Cheng \& Kwan } \\
(2000)\end{array}$ & Chinese regions & $\begin{array}{l}\text { Province/municipali } \\
\text { ty-level data, panel } \\
\text { regression }\end{array}$ & $\begin{array}{l}\text { Previous FDI }(+) \\
\text { Wage }(-) \\
\text { Per capita income }(+) \\
\text { Senior education }(+) \\
\text { High grade paved roads }(+) \\
\text { Special Economic Zone }(+)\end{array}$ \\
\hline $\begin{array}{l}\text { Guimaraes et al. } \\
(2000)\end{array}$ & $\begin{array}{l}\text { Portuguese } \\
\text { regions/ } \\
\text { concelhos }\end{array}$ & $\begin{array}{l}\text { Regional and firm- } \\
\text { level data, panel } \\
\text { regression }\end{array}$ & $\begin{array}{l}\text { Total manufac employ/ } \mathrm{km}^{2}(+) \\
\text { Share of manufac employment in } \\
\text { same 3-digit SIC as investor }(+) \\
\text { Share of employment in foreign } \\
\text { plants (-) } \\
\text { Share of total employment in } \\
\text { tertiary sector (+) } \\
\text { Index of manufac wage (+) } \\
\text { Secondary education (+) } \\
\text { Population density (+) } \\
\text { Distance (to Lisbon and Porto) (- } \\
\text { ) }\end{array}$ \\
\hline List (2001) & $\begin{array}{l}\text { Californian } \\
\text { counties }\end{array}$ & $\begin{array}{l}\text { County and firm- } \\
\text { level data, Piosson } \\
\text { and ZIP regression }\end{array}$ & $\begin{array}{l}\text { New plants (+) } \\
\text { Pollution regulation (-) } \\
\text { Wage }(-) \\
\text { Population density }(+) \\
\text { Land area }(+) \\
\text { Per capita property tax }(+)\end{array}$ \\
\hline $\begin{array}{l}\text { Belderbos \& } \\
\text { Carree (2002) }\end{array}$ & Chinese regions & $\begin{array}{l}\text { Japanese } \\
\text { electronics sector- } \\
\text { level data, panel } \\
\text { regression }\end{array}$ & $\begin{array}{l}\text { Industry agglomeration (+) } \\
\text { Japanese agglomeration (+) } \\
\text { Keiretsu agglomeration (+) } \\
\text { GDP (+) } \\
\text { Phone lines per capita (-) } \\
\text { GDP per capita (+) } \\
\text { Wage levels (-) } \\
\text { Distance from Japan (-) } \\
\text { Seaport (+) } \\
\text { SEZ-OCC share (+) }\end{array}$ \\
\hline $\begin{array}{l}\text { Deichmann et al. } \\
\text { (2003) }\end{array}$ & Turkish regions & $\begin{array}{l}\text { Regional and firm- } \\
\text { level data, cross- } \\
\text { section regression }\end{array}$ & $\begin{array}{l}\text { GDP per capita (+) } \\
\text { Proportion paved roads (+) } \\
\text { Sea access (+) } \\
\text { Student/ teacher ratio (-) } \\
\text { Bank credit/ GDP (+) } \\
\text { Agricultural value/ GDP (-) } \\
\text { Previous FDI (+) } \\
\text { Public investment/ GDP (-) }\end{array}$ \\
\hline Tuan \& Ng (2004) & $\begin{array}{l}\text { Chinese cities/ } \\
\text { counties }\end{array}$ & $\begin{array}{l}\text { City-level data, } \\
\text { cross-section } \\
\text { regression }\end{array}$ & $\begin{array}{l}\text { Resident income }(+) \\
\text { Fixed assets per area }(+) \\
\text { Relative wage }(+) \\
\text { Manufacturing base }(+)\end{array}$ \\
\hline $\begin{array}{l}\text { Crozet et al. } \\
(2004)\end{array}$ & French regions & $\begin{array}{l}\text { Firm-level data, } \\
\text { panel regression }\end{array}$ & $\begin{array}{l}\text { Market potential }(+) \\
\text { Average wage }(-) \\
\text { Agglo - home country firms }(+) \\
\text { Agglo - other foreign firms }(+)\end{array}$ \\
\hline
\end{tabular}




\begin{tabular}{|l|l|l|}
\hline & & $\begin{array}{l}\text { Agglo - other French firms (+) } \\
\text { Distance to home country (-) }\end{array}$ \\
\hline
\end{tabular}

Table A: Summary of recent research (continued)

\begin{tabular}{|c|c|c|c|}
\hline Author(s) & Location & Data and method & Determinants \\
\hline Roberto (2004) & Italian provinces & $\begin{array}{l}\text { Province and } \\
\text { sector-level data, } \\
\text { Panel regression }\end{array}$ & $\begin{array}{l}\text { Electrical consumption (+) } \\
\text { Manufacturing in the province (+) } \\
\text { Manufacturing in adjacent } \\
\text { provinces (-) } \\
\text { Foreign owned plants (+) } \\
\text { Foreign owned plants in adjacent } \\
\text { provinces (+) } \\
\text { Index of infrastructure (+) } \\
\text { Avg labour cost/ productivity (-) } \\
\text { Unemployment rate (-) }\end{array}$ \\
\hline $\begin{array}{l}\text { Boudier-Bensebaa } \\
\text { (2005) }\end{array}$ & $\begin{array}{l}\text { Hungarian } \\
\text { regions }\end{array}$ & $\begin{array}{l}\text { County-level data, } \\
\text { panel regression }\end{array}$ & $\begin{array}{l}\text { Labour availability (+) } \\
\text { Industrial demand }(+) \\
\text { Manufacturing density (+) } \\
\text { Other FDI enterprises (+) } \\
\text { Roads infrastructure (+) }\end{array}$ \\
\hline $\begin{array}{l}\text { De Propris et al. } \\
\text { (2005) }\end{array}$ & Italian provinces & $\begin{array}{l}\text { Province and } \\
\text { sector-level data, } \\
\text { Panel regression }\end{array}$ & $\begin{array}{l}\text { LQ for local industrial system (+) } \\
\text { Marshallian industrial districts }(+) \\
\text { Exports per employee*LIS }(+) \\
\text { Average firm size }(+)\end{array}$ \\
\hline Gao (2005) & $\begin{array}{l}\text { Chinese } \\
\text { provinces/ } \\
\text { municipalities }\end{array}$ & $\begin{array}{l}\text { Province/municipali } \\
\text { ty-level data, panel } \\
\text { regression }\end{array}$ & $\begin{array}{l}\text { Real GDP }(+) \\
\text { Real wage }(-) \\
\text { Transport infrastructure }(+) \\
\text { Primary schooling }(+) \\
\text { Junior Schooling }(+) \\
\text { Senior schooling }(+) \\
\text { College }(+) \\
\text { SEZs }(+)\end{array}$ \\
\hline $\begin{array}{l}\text { Cassidy \& } \\
\text { Andreosso- } \\
\text { O'Callaghan } \\
\text { (2006) }\end{array}$ & $\begin{array}{l}\text { Chinese } \\
\text { provinces// } \\
\text { municipalities }\end{array}$ & $\begin{array}{l}\text { Province/municipali } \\
\text { ty-level data for } \\
\text { Japanese FDI, } \\
\text { cross-section } \\
\text { regression }\end{array}$ & $\begin{array}{l}\text { Provincial GDP }(+) \\
\text { Tertiary education }(+) \\
\text { Coastal location }(+) \\
\text { Inland waterways }(+) \\
\text { Efficiency wages }(+)\end{array}$ \\
\hline $\begin{array}{l}\text { Cheng \& Stough } \\
\text { (2006) }\end{array}$ & $\begin{array}{l}\text { Chinese } \\
\text { provinces/ } \\
\text { municipalities }\end{array}$ & $\begin{array}{l}\text { Province/municipali } \\
\text { ty-level data for } \\
\text { Japanese FDI, } \\
\text { panel regression }\end{array}$ & $\begin{array}{l}\text { Labour cost }(+) \\
\text { Land cost }(-) \\
\text { JFDI agglomeration }(+) \\
\text { Length of openness }(+) \\
\text { Number of national zones }(+) \\
\text { Labour quality }(+)\end{array}$ \\
\hline $\begin{array}{l}\text { Bobonis \& Shatz } \\
\text { (2007) }\end{array}$ & U.S. states & $\begin{array}{l}\text { State-level data, } \\
\text { panel regression } \\
\text { (AB specification) }\end{array}$ & $\begin{array}{l}\text { Agglomeration (+) } \\
\text { Gross state product }(+) \\
\text { GSP of adjacent states }(-) \\
\text { Change in state revenues }(+) \\
\text { Remoteness (+) } \\
\text { Home country GDP }(+) \\
\text { Real wage }(-) \\
\text { Unemployment rate }(+) \\
\text { Union coverage rate }(-) \\
\text { Corporate tax rate }(-) \\
\text { Foreign exemption }{ }^{\star} \text { taxes }(-)\end{array}$ \\
\hline
\end{tabular}


KRUGELL W

Measuring the Inward FDI Potential

MATTHEE M of South African Regions

\begin{tabular}{|l|l|l|l|}
\hline & & & $\begin{array}{l}\text { Unitary tax }(-) \\
\text { Real PPE }(+) \\
\text { Real PPE adjacent states }(+)\end{array}$ \\
\hline Bronzini (2007) & Italian provinces & $\begin{array}{l}\text { Province and } \\
\text { sector-level data, } \\
\text { Panel regression }\end{array}$ & $\begin{array}{l}\text { Sector specialisation }(+) \\
\text { Diversity HH Index }(-) \\
\text { Firm size }(-)\end{array}$ \\
\hline
\end{tabular}

